\title{
FAPUSZTULÁS ÉS GYORSULÓ NÖVEKEDÉS KOCSÁNYTALAN TÖLGYESEINKBEN
}

\author{
Berki Imre', Móricz Norbert², Rasztovits Ervin², Gulyás Krisztina³, Garamszegi Balázs², \\ Horváth Adrienn ${ }^{1}$, Balázs Pál1 és Lakatos Bence ${ }^{1}$ \\ ${ }^{1}$ Soproni Egyetem, Erdömérnöki Kar \\ ${ }^{2} N A I K$ Erdészeti Tudományos Intézet \\ 3Észak-magyarországi Vízügyi lgazgatóság
}

\begin{abstract}
Kivonat
Hazánkban a klímaváltozással együtt járó aszályok évtizedek óta fapusztulásokat okoznak kocsánytalan tölgyesekben is. Másfelöl több hazai publikáció született e fafaj növekedésének gyorsulásról, de lassulásáról is. Vizsgáltuk, hogy van-e növekedésgyorsulás a száraz klímájú kocsánytalan tölgyes termőhelyeken, ahol évtizedek óta számottevő a kigyérülés a középkorú és az idősebb állományokban. Eredményeink szerint száraz tájainkon is egyértelmüen gyorsult a fiatal kocsánytalan tölgyesek magassági növekedése. Az évtizedek óta időszakonként fellépő fapusztulás, valamint ezzel szemben a magassági-növekedés gyorsulása mégsem ellentmondásos. A fentiekböl nem következik, hogy a többlet növekedés a jövőben is jellemző lesz, mert a klíma elörejelző modellek szerint az aszálygyakoriság növekvő tendenciát fog mutatni.
\end{abstract}

Kulcsszavak: klímaváltozás, aszály, kocsánytalan tölgy, fapusztulás, növekedésgyorsulás.

\section{MORTALITY AND ACCELERATING GROWTH IN SESSILE OAK SITES}

\begin{abstract}
The drought-induced vitality loss of sessile oak (Quercus petraea (Matt.) Liebl.) has been continuously observed in Hungary for more than three decades. On the other hand there are some publications about the accelerated and decelerating growth of this tree species in Hungary. The changing height growth was studied on dry sessile oak sites to decide the presence or absence of the accelerated growth of young stands neighbouring older one with mass mortality in the last decades. Results showed a significant accelerated height growth of young stands in dry landscapes. The mass mortality and the accelerated growth of sessile oak stands in the dry landscapes are not contradictory.
\end{abstract}

Keywords: climate change, dry extrems, sessile oak, tree decay, accelerating growth. 


\section{BEVEZETÉS}

Nyugat-Európában és Észak-Amerikában az „új típusú” erdőpusztulások az 1970-es években kezdődtek és okaival számos kutató foglalkozott (pl. Ulrich 1989, Manion 1992). Megállapították, hogy a pusztulások egyik fő oka a lokális, vagy regionális, túlnyomóan kéndioxidos légszennyezés, amely a talaj savanyitásán keresztül is elősegíti a pusztulást. Az iparvidékektöl távoli pusztulásokban viszont már akkor is a száraz időszakok jelentették a döntő okot (Rehfuess 1986).

Az 1980-as (és 90-es) években a kén-dioxid emisszió drasztikus csökkentésével szinte teljességgel megszüntek a légszennyezés eredetü fapusztulások, és egyre több publikáció jelent meg az erdei fafajok gyorsuló növekedésérő, amelynek okáull elsősorban a globális melegedést jelölték meg (pl. Becker 1991, Spiecker et al. 1996).

Megjegyezzük, hogy a kontinens nyugati felén a klímaváltozás nem járt együtt olyan mértékü - fapusztulást és a növekedés lassulását okozó - szárazodással, mint Közép-Európa délkeleti felén és Dél-Európában. Bertini et al. (2010) ki is mutatta, hogy Olaszországban a klímaváltozás hatására csökkent a kocsánytalan tölgy növekedése.

Később a Nyugat-Európában tapasztalt növedékgyorsulás inspiráló hatására hazai mérések és elemzések is indultak, amelynek eredményei szerint bizonyos mértékü gyorsuló növekedés a hazai erdőkben is tapasztalható (Somogyi 2007, Somogyi 2008, Szabados 2007).

\section{CÉLKITŰZÉS}

Hazánk szárazságra hajló tájainak kocsánytalan tölgyeseiben az elmúlt évtizedek egyre gyakoribb száraz időszakainak hatására számottevő fapusztulás zajlott. Ugyanakkor az ország még viszonylag jobb nedvességellátottságú tájain mérsékelt növekedésgyorsulás is kimutatható volt. Jelen kutatás célja annak vizsgálata, hogy:

- Milyen szoros az összefüggés tájaink nedvességellátottsága és a kocsánytalan tölgy pusztulásának mértéke között.

- Van-e növekedésgyorsulás az olyan mezofil és száraz kocsánytalan tölgy termőhelyeken is, ahol évtizedek óta jelentős a fapusztulás.

\section{A VIZSGÁLT ÁLLOMÁNYOK ÉS AZ ALKALMAZOTT MÓDSZEREK}

\section{Kocsánytalan tölgyesek fapusztulás okozta törzshiányának megállapítása országos klímagradiens mentén}

A kocsánytalan tölgy a leghumidabb tájaktól a száraz tájakig állományalkotó, és az elmúlt évtizedekben a szárazodás hatására elterjedésének szárazabb tájain számottevő pusztulást 
mutatott. E két jellegzetessége miatt alkalmas a klímafüggő pusztulás, illetve a növekedésgyorsulás klimatikus okainak vizsgálatára. Már négy évvel ezelőtt is beszámoltunk a kocsánytalan tölgy egészségi állapotáról (Berki et al. 2014). Vizsgált helyszíneink az országon átnyúló klímatranszekt mentén, 3-4 évtizede nem gyérített (legfeljebb száradékolt), zonális termőhelyü, középkorú és idős állományok voltak. Jelenlegi kutatásunkban a fapusztulások okozta törzshiány megállapításához bővítettük a vizsgált állományok számát.

Erdőállományok vizsgálata klímatranszekt mentén általánosan ismert módszer (pl. Pretzsch \& Schütze 2012). A száraz időszakok miatti fapusztulások következtében lecsökkent relatív állománysürüséget, és az így kialakult törzshiányt úgy határoztuk meg, hogy a vizsgált állományok hektáronkénti törzsszámát Béky (1981) mageredetű kocsánytalan tölgy fatermési tábla (100\%-os záródású állományokra vonatkoztatott) törzsszámaihoz viszonyítottuk. E módszer részleteit e folyóiratban megjelent korábbi közleményünk (Berki et al. 2014) tartalmazza.

Az egyes tájak klímajellemzésére választott Ellenberg-index a legmelegebb hónap középhőmérsékletének és a csapadék éves mennyiségének aránya (T július C / P éves mm) x 1000), és alkalmas a nyári szárazság mértékének kifejezésére.

\section{A vizsgált kocsánytalan tölgy állományok felső magasságának mérése és a relatív felső magasság}

Egy erdei termőhely termőképességét a rajta növő faállomány (dendrometriai paraméterei közül) a magassági növekedés jelzi a legvalósabban. A felső magasság függ legkevésbé az állomány sürüségétől (gyérülésétől) ezért a felső magasság és az állomány fatérfogata a termőhely produktivitásának indikátora. Számos publikáció azt is megerősíti, hogy a magassági növekedés változása jelzi legpontosabban a klímaváltozás faállományokra gyakorolt hatását (pl. Libiete-Zalite \& Jansons 2012).

Az általunk vizsgált kocsánytalan tölgy állományokban egy hektár területet bejárva a vizuálisan legmagasabbnak itélt 20-25 faegyed magasságát mértük. E megmért fák közül a legmagasabb 7-8 fa (a mért faegyedek egyharmada) átlagmagasságát tekintettük az állomány felső magasságának. Jóllehet e módszer nem megszokott módja az állományi felső magasság meghatározásának, de viszonylag gyors és pusztán a vizsgált állományoknak a relatív felső magasság alapján, egymással történő összehasonlítására messzemenően alkalmas.

A fák magassági növekedése szoros összefüggésben van a klímával, és ezen belül a nedvességellátottsággal, éppen ezért az állományok felső magasságát is a nedves - száraz klímatranszekt mentén mértük.

Egy faállomány magassága a terepen (általában tized méter pontossággal) megmért abszolút érték. A relatív magasság pedig azt fejezi ki, hogy az adott életkorig ez a magasság gyenge, vagy jó magassági növekedésre utal. A faállományokat magassági növekedési teljesítményük alapján a fatermési tábla hatféle fatermési osztályba sorolja be. 
Vizsgálatunkban az idősebb kocsánytalan tölgy állományok eddigi magassági növekedési teljesítményéhez (relatív magasságához) viszonyítjuk a fiatal állomány eddigi növekedését (relatív magasságát). Ezt kétféle módon is megtehetjük. Az egyik módszer, hogy a Béky-féle mageredetű kocsánytalan tölgyek fatermési tábláiban (Béky 1981) az idősebb állomány fatermési osztályát tekintjük alapnak, és ennek korfüggő értékeihez viszonyítjuk az idősebb és a fiatal állomány magassági értékét, majd összevetjük egymással az idősebb és a fiatal állomány ezen értéktől való eltéréseit. A másik módszer szerint minden vizsgált helyszín idősebb és fiatal állományainak magasságát egységesen a közepes (III.) fatermési osztály (korfüggö) értékeihez viszonyítunk, és százalékban fejezzük ki. Az összehasonlításainkat minkét módszer szerint elvégeztük és a kapott eredmények szinte teljességgel egyeztek. Utóbbi módszer eredményei szemléletesebben ábrázolhatók, így jelen publikációban ezeket mutatjuk be.

\section{A kocsánytalan tölgy magassági növekedés változásának vizsgálata szomszédos fiatal és idősebb állományok relatív felsőmagasságának összevetésével}

Hazánkban a klíma melegedése az 1980-as évektől lett fokozott mértékü, és szintén ettől váltak gyakoribbá a több évre kiterjedő aszályos időszakok. Tehát a klímaváltozás a faállomány növekedésére gyakorolt hatását az 1980-as években felújított, így jelenleg 30-35 éves állományok magassági növekedésén lehet lemérni.

E fiatal állományok növekedését nem tudjuk megfelelő standardhoz viszonyítani, hiszen a klímaváltozás minden táj, minden fafajának, minden korosztályára hat. Viszonyíthatjuk ugyanakkor a megváltozott körülmények között nőtt fiatal állományok növekedési teljesítményét a fiatal állományok szomszédságában álló, számottevően idősebb állomány növekedési teljesítményéhez. Ebben az esetben ugyanis az egyes helyszíneken a fiatal és a szomszédos idősebb állomány termőhelye hasonló, de míg a fiatal állomány eddigi teljes életidejét már a melegebb és szárazabb klímában töltötte, addig a szomszédos idősebb állomány eddigi életidejének csak egy részét - ráadásul idősebb, már lassuló növekedésmenetü - életszakaszát élte a megváltozott környezetben. Ha a fiatal állományok felső magassága nagyobb, mint az idősebbeké, akkor a növekedést gyorsitó hatások erösebbek, mint a gyakori száraz időszakok növekedést fékező hatása.

Az állománysürüségi és törzshiány vizsgálatok 32 db állománya közül csak 12 szomszédságában volt 25-35 év közötti korú fiatal állomány is, így további 16 db olyan idősebb (80-120 éves) állományokat jelöltünk ki, amelyeknek voltak fiatal szomszédjai. Így összesen 28 helyszínen hasonlítottuk össze a két korosztály relatív felső magasságát. 


\section{Terepi mérések helyszínei}

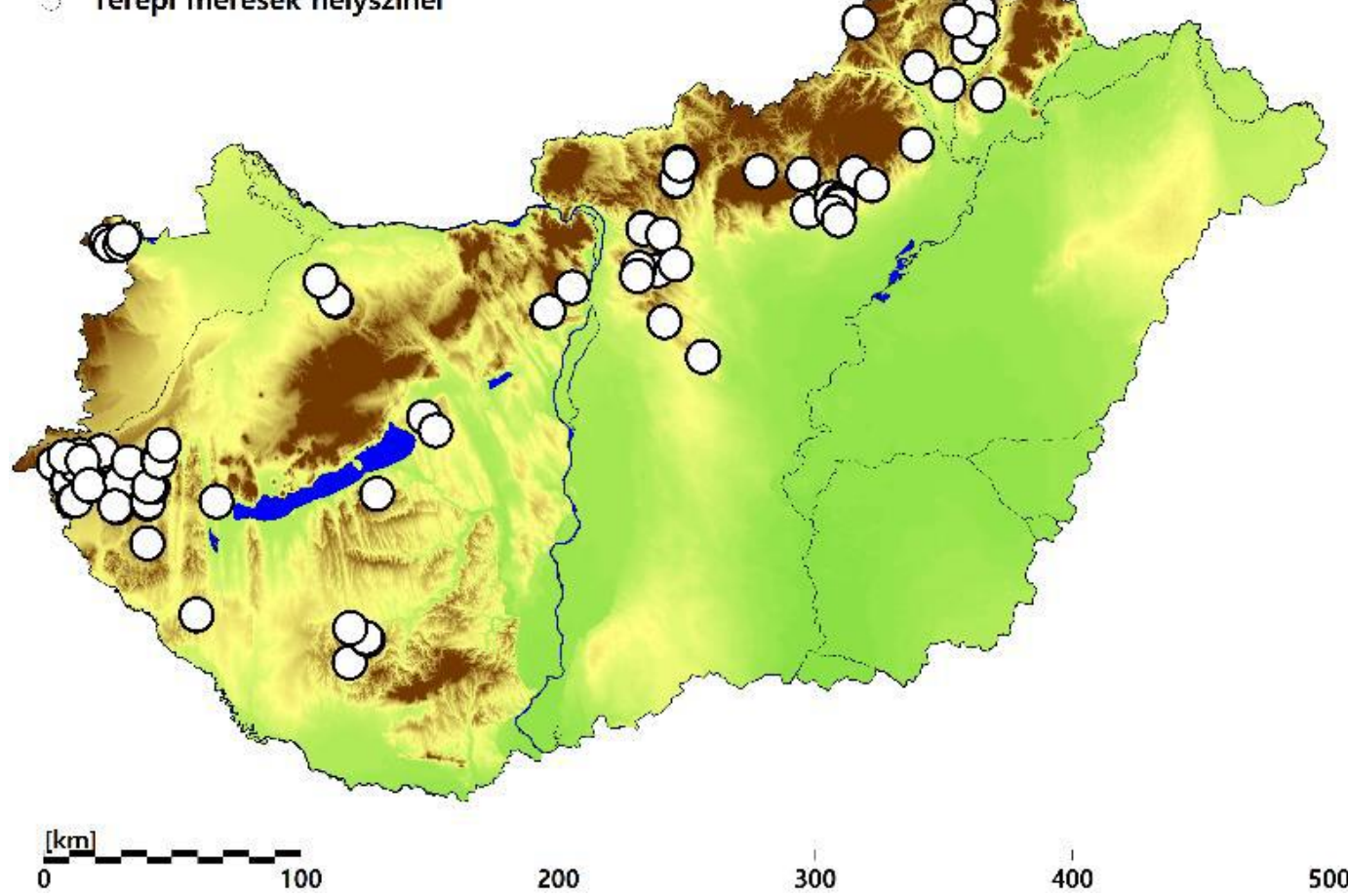

1. ábra: A kocsánytalan tölgy állományok relatív sürüségének és felső magasságának mérési helyszínei az országot átszelő dombsági magasságú helyszínek alkotta klímatranszekt mentén.

Figure 1: Selected sessile oak stands for density and growth investigations in zonal hilly sites along a climatic gradient through Hungary.

\section{EREDMÉNYEK}

\section{A szárazság okozta fapusztulás miatti állománysűrüség csökkenés (gyérülés, törzshiány)}

A nedves-száraz klímatranszekt mentén vizsgált állományokban 112\% -ról $57 \%$-ig csökken a relatív állománysürüség (1. ábra), föleg a száraz alföldperemi, dombsági tájakon volt olyan jelentős fapusztulás a gyakoribbá és hosszabbá vált aszályok hatására, hogy drasztikusan csökkent az állományok relatív sürüsége, és alakult ki jelentős élőfakészlet hiány.

A 2. ábrán látható klímaszárazodás-mortalitás függvény segítségével becsülhető, hogy adott Ellenberg-index értékkel jellemzett klíma mellett milyen mértékủ kocsánytalan tölgypusztulás várható. A különböző klímaszcenáriók szerint a jövőben tovább szárazodik a Kárpát-medence klímája (Gálos et.al. 2015) 


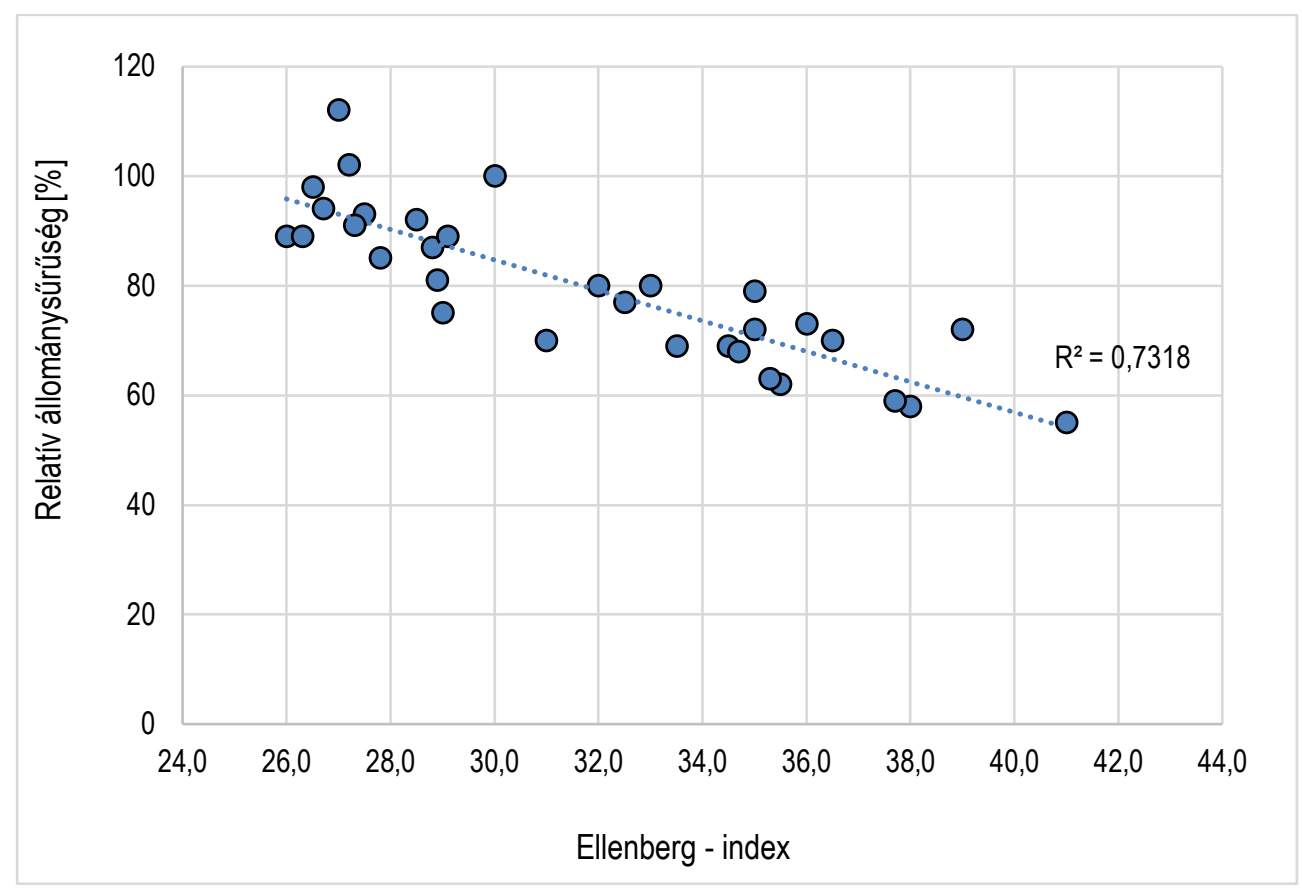

2. ábra: Kocsánytalan tölgy állományok Ellenberg-indexel kifejezett klímája (1961-2010) és relatív sürüségük közötti összefüggés.

Figure 2: Relationship between the climate (1961-2010) and the relative density of the sessile oak stands along a climatic gradient through Hungary.

\section{Szomszédos idős és fiatal kocsánytalan tölgy állományok relatív felsőmagassága}

A 3. ábra a vizsgált kocsánytalan tölgyes helyszíneken, az azonos Ellenberg-index értékü fiatal és idős állományok relatív magaságát mutatja (zöld és barna pontok). Látható, hogy az idős és a fiatal állományok legintenzívebb magassági növekedése nem a leghumidabb (őrségi) klímában van, hanem a 28-29-es Ellenberg-indexü (göcseji) állományokban, az örséginél kedvezőbb talaj adottságok miatt. Ezután a mezofil-száraz irányban (nagyobb index értékek felé) haladva a felső magasság csökkenése jól követi a növekvő vízhiányt. 


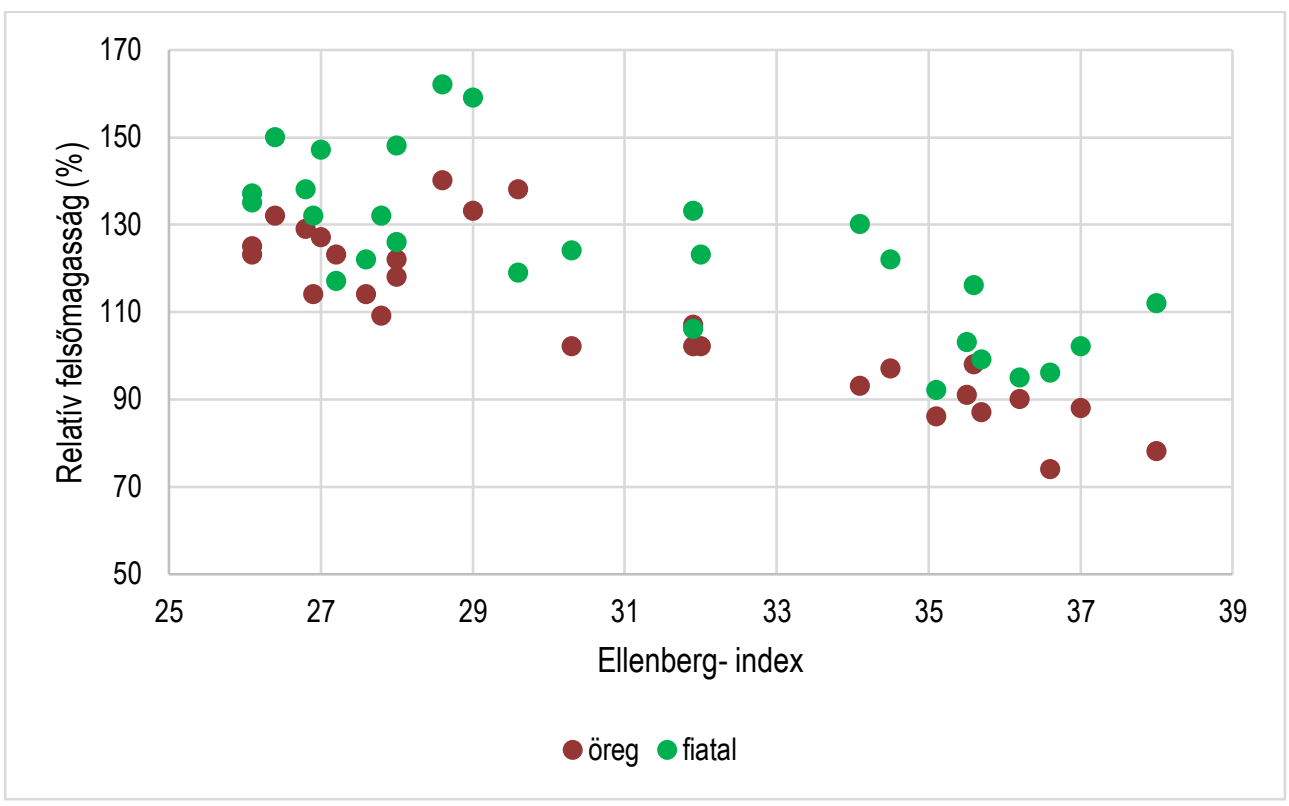

3. ábra: A vizsgált idős-fiatal KTT állománypárok relatív felső magassága. Adott helyszín idősebb és fiatalabb állománya ugyanazon Ellenberg-index értéknél van.

Figure 3: Relative top height of young and older sessile oak stands. Green point $=$ young stand, brown point $=$ older stand .

A 3. ábra fontos mondanivalója az, hogy az egyes helyszíneken a fiatalabb állományok relatív felső magassága rendre nagyobb, mint az idősebbeké, tehát gyorsabban növekednek, mint az idősebb állományok fiatalabb korukban. A meglepő az, hogy a klímatranszekt száraz részén is gyorsult a magassági növekedés az utóbbi évtizedekben, miközben ott számottevő fapusztulás is zajlott.

\section{A fiatalabb/idősebb állomány relatív magasságának aránya}

A könnyebb áttekinthetőség kedvéért az egyes helyszíneken levő fiatal és idősebb állomány relatív felső magasságának viszonyát oly módon is bemutatjuk, hogy adott helyszín fiatal állományának relatív felső magasságát osztottuk a szomszédos idősebbével. A kapott értéket százalékos formában ábrázoltuk a 4. ábrán, amelyen látható, hogy a 28 idős-fiatal állománypár közül 26 helyszínen van 100\% fölötti érték, 115-120\% közötti átlagértékekkel. Megállapíthatjuk tehát, hogy átlagosan 15-20\%-kal nagyobb a fiatal állományok relatív felső magassága a fatermési táblához képest, mint az idősebbeké. 


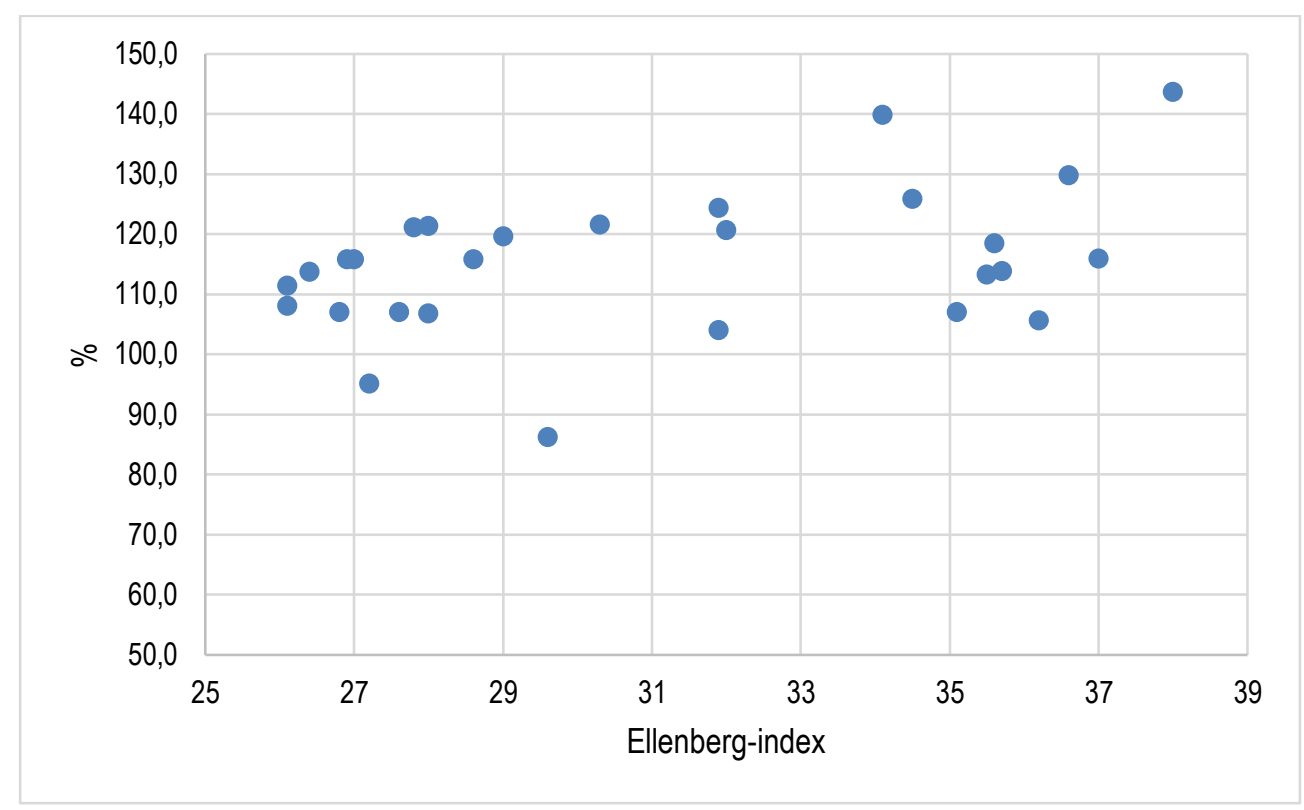

4. ábra: A szomszédos fiatal / idős állománypárok relatív felsőmagasság arányának százalékban kifejezett hányadosa.

Figure 4: The rate of relative top height of young / neighbouring older stand (in \%).

Függ-e a kocsánytalan tölgy magassági növekedése az állomány relatív sürűségétöl?

A fiatal állományok relatív felső magasságát tehát a szomszédos idősebb állomány relatív felső magasságához viszonyítottuk, ezért fontos tudni, hogy az idősebb állomány felső magasságát nem csökkenti-e a fapusztulások miatt lecsökkent állománysürüség.

Elemeznünk tehát, hogy a vizsgált idősebb állományokban milyen mértékben függ a felső magasság az állomány relatív sürüségétől. Mivel a zonális termőhelyű állományok magassági növekedése döntően a klímától függ, ezért, ha a magassági növekedés állománysürüségtől való esetleges függését akarjuk megtudni, akkor a hasonló klímájú, de eltérő sürüségü állományok relatív felső magasságát kell összehasonlítani. Az 5. ábrán 19 db cserestölgyes klímájú, középkorú és idősebb kocsánytalan tölgy állomány relatív felső magasságát ábrázoltuk relatív állománysürüségük függvényében. 


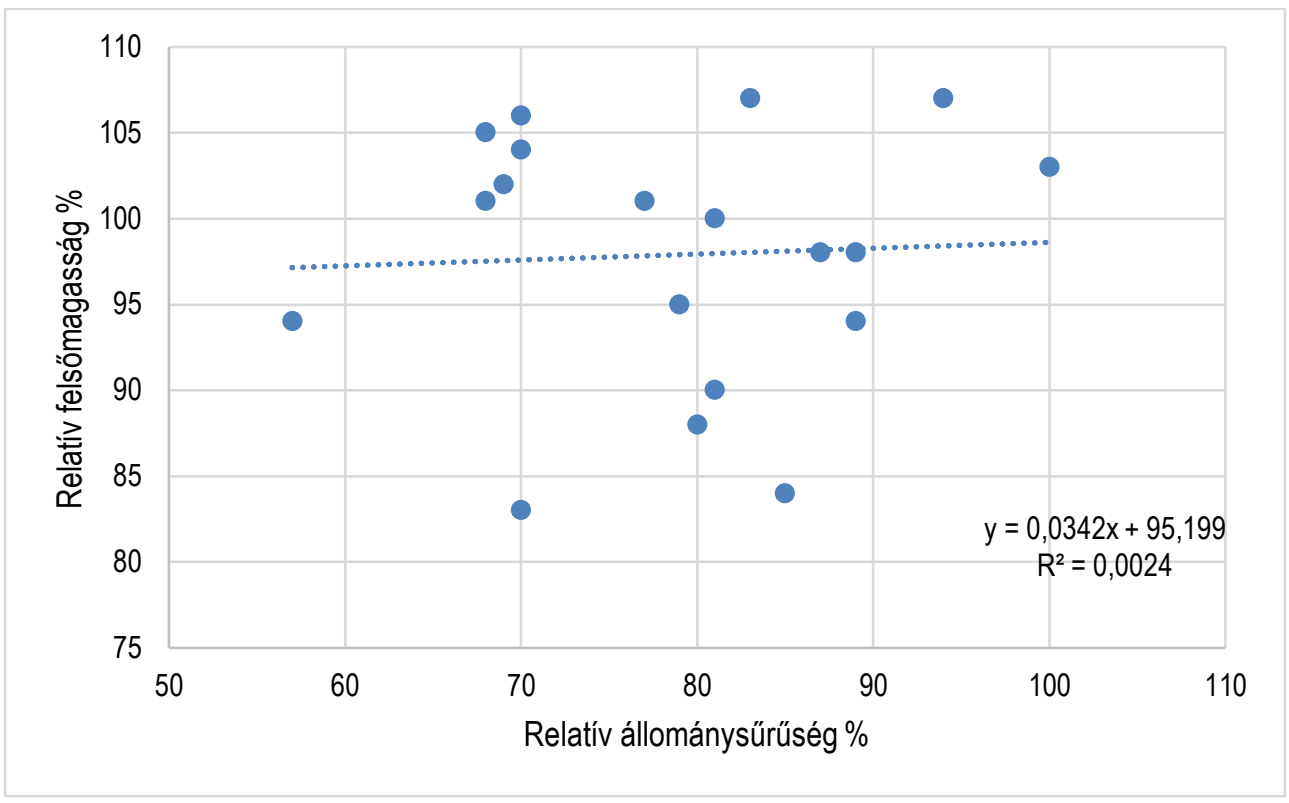

5. ábra: Hasonlóan cseres-tölgyes klímájú, de különböző relatív állománysürüségü (\%), középkorú és idősebb kocsánytalan tölgy állományok relatív felső magassága (\%).

Figure 5: Relationship between relative stand density and relative top height of older sessile oak stands with similar (Turkey-sessile oak) climate (in \%).

Ezen állományok klímája eléggé hasonló, Ellenberg-indexük 33,0-36,2 értékek közé esik. Az állományok relatív sürüsége viszont széles spektrumú, mert 57\%-tól 100\% közötti. Eltérő relatív felső magasságukat nem az eltérő állománysürüség okozza, mert az összefüggés nem szignifikáns.

\section{Az idősebb állományok fapusztulásának mértéke és a szomszéd fiatal állományok növekedésmenetének változása az idősebbekhez képest}

Az eredmények bemutatásának elején a 2. ábrán láthattuk, hogy a klímatranszekt mentén vizsgált 32 db középkorú és idős állományokat a száraz tájak felé haladva egyre nagyobb mértékű fapusztulás jellemezte az elmúlt évtizedekben. A 4. ábrán pedig azt láttuk, hogy az idősebb állományok relatív magasságát 100\%-nak véve a fiatal fiatalok relatív magassága rendre $100 \%$ fölötti, tehát gyorsabban nőttek, mint az idősebbek fiatalabb korukban. A szemléletesség kedvéért e két jelenséget egy ábrán is bemutatjuk (6. ábra).

Az idősebb állományok relatív sürüségéhez (kigyérüléséhez) két okból sem a saját, hanem a szomszédos fiatal állományok növekedésgyorsulását hasonlítottuk Egyrészt azért, mert a saját növekedésgyorsulásuk nem ismert, másrészt azért, mert - ahogy a módszertani 
részben kifejtettük - nem az idősebb, hanem a fiatalabb állományok élték eddigi teljes életszakaszukat abban a megváltozott klímában, amelynek száraz időszakai fapusztulást, tehát állománygyérülést okoztak a középkorú és idősebb állományokban.

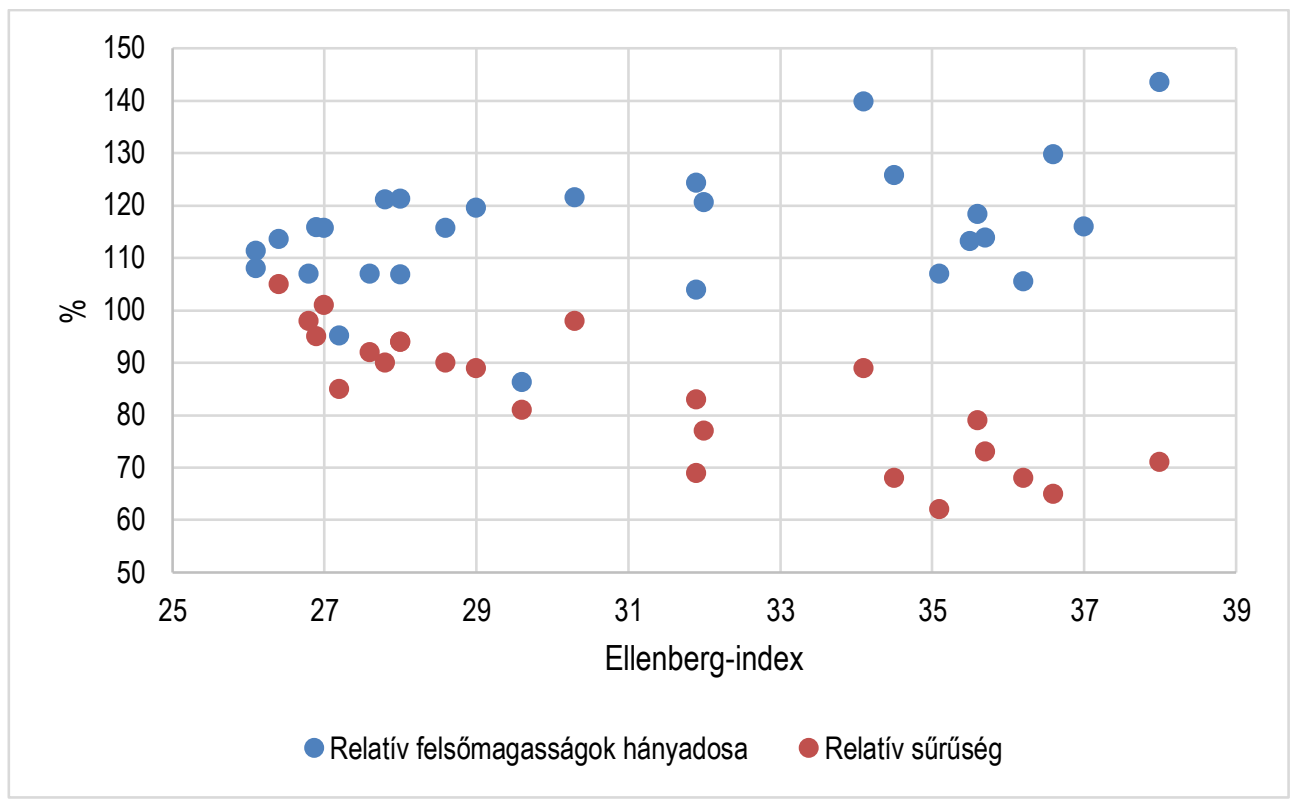

6. ábra: A fiatal állományok relatív felsőmagassága (\%) (kék pontok), és a szomszédos idősebb állományok relativ állománysürüsége (barna pontok) összehasonlitása, a klíma függvényében.

Figure 6: The rate of relative top height of young / neighbouring older stand (in \%, blue point), and the relative stand density of older stands (in \%, brown point).

A 6. ábrán látható, hogy a humid tájaktól a szárazak felé haladva az idősebb állományokban a száraz időszakok hatására bekövetkezett fapusztulás miatt fokozatosan csökken az állománysürüség, és kb. a 32-es Ellenberg-index értéknél szárazabb helyszíneken számottevő törzshiány alakult ki. Meglepő, hogy e száraz tájakon is gyorsuló növekedésüek a fiatal állományok.

\section{KONKLÚZIÓ}

Vizsgálataink legfontosabb megállapítása tehát az, hogy az eddigi életszakaszukat a megváltozott atmoszférikus környezetben töltő fiatal állományok a teljes klímatranszekt mentén gyorsabban nőttek, mint ahogy az idősebb állományok nőttek fiatalabb korukban. Meglepő, hogy a szárazságokkal erősebben sújtott tájakon is gyorsult a fiatal állományok magassági növekedése, pedig a szomszédos idősebb állományokban az utóbbi 3 évtized- 
ben a száraz időjárási extrémek miatt számottevő fapusztulás volt. A vizsgálatunkban viszonyítási alapnak tekintett idősebb állományok növekedése is valamennyivel feltételezhetően gyorsuló lett, így a fiatal állományok 15-20\%-os növekedésgyorsulása alábecsült érték.

Feltehető, hogy az idősebb állományokban történt fapusztulások miatti állománygyérülés (törzshiány) következtében hektáronkénti fatérfogatuk kisebb, mint amekkorát korukból és magasságából adódóan a fatermési tábla mutat.

Az évtizedek óta időszakonként fellépő fapusztulás, valamint ezzel szemben a magassági növekedés gyorsulása mégsem ellentmondásos folyamatok. A klímaváltozással együtt járó száraz extrémek jóllehet időszakonként fapusztulásokat okoztak, de egyenlöre csak feltételezzük, hogy az elmúlt évtizedekben többségben lehettek az olyan az évek, amelyekben volt legalább annyi csapadék, hogy a fák nedvességellátottsága elegendő volt a melegebb és hosszabb vegetációs időszak növekedésfokozó érvényesüléséhez. Kutatásunk következő feladata, hogy évgyürü analízissel számszerüsítsük az elmúlt 3-4 évtized növekedést fékező, illetve gyorsít hatású éveinek számát.

Az elmúlt évtizedekben tehát az országon átívelő klímagradiens túlnyomó részén a fapusztulások ellenére növedékgyorsulás volt, de ebböl nem következik, hogy a többletnövekedés a jövőben is jellemző lesz, mert a klíma elörejelző modellek szerint az aszály gyakoriság növekvő tendenciát fog mutatni (Gálos et al. 2015).

\section{KÖSZÖNETNYILVÁNÍTÁS}

A kutatást az Agrárklíma.2 (VKSZ 12-1-2013-0034) projekt támogatta.

\section{FELHASZNÁLT IRODALOM}

Becker M. 1991: Impact of climate, soil and silviculture on forest growth and health. In: Landmann (ed): French research into forest decline. DEFORPA Programme (Forest decline and air pollution), $2^{\text {nd }}$ report, Nancy, 23-38.

Béky A. 1981: Mag eredetü kocsánytalan tölgyesek fatermése. Erdészeti kutatások 74: 309-320.

Berki I., Rasztovits E. \& Móricz N. 2014: Erdőállományok egészségi állapotának értékelése - egy új megközelítés. Erdészettudományi közlemények 4(2): 149-155.

Bertini G., Amoriello T., Fabbio G. \& Piovosi M. 2010: Forest growth and climate change: evidences from the ICP-Forests intensive monitoring in Italy. iForest 4: 262-267. DOI: 10.3832/ifor0596-004

Gálos B., Führer E., Czimber K., Gulyás K., Bidló A., Hänsler A. et al. 2015: Climatic threats determining future adaptive forest management - a case study of Zala County. Időjárás 119(4): 425-441.

Libiete-Zalite Z. \& Jansons A. 2012: Climate impacts on lodgepole pine (Pinus contorta var. latifolia) height growth in Latvia. Joint International Conference „Biological Reactions of Forests to Climate Change and Air Pollution" Kaunas, Lithuania.

Manion P.D. 1992: Forest Decline Concepts (first edition). American Phytopathological Society, St Paul, Minnesota, USA.

Pretzsch H. 2009: Forest dynamics, growth and yield - From measurement to model. Spinger-Verlag Berlin Heidelberg. DOI: 10.1007/978-3-540-88307-4 
Pretzsch H., Schütze G. \& Uhl E. 2012: Resistance of European tree species to drought stress in mixed versus pure forests: evidence of stress release by inter-specific facilitation. Plant Biology 15(3): 483-495. DOI: 10.1111/j.1438-8677.2012.00670.x

Rehfuess K.E. \& Bosch C. 1986: Experimentelle Untersuchungen zur Erkrankung der Fichte (Picea abies (L.) Karst.) auf saueren Böden der Hochlagen: Arbeitshypothese und Versuchsplan. Forstwissenschaftliches Centralblatt 105(1): 201-206. DOI: 10.1007/bf02741714

Somogyi Z. 2007: A klíma, a klímaváltozás és a fanövedék néhány összefüggéséröl. In: Mátyás Cs. \& Vig P. (eds): Erdő és klíma V., Nyugat-Magyarországi Egyetem, Sopron, 281-294.

Somogyi Z. 2008: Recent trend of tree growth in relation to climate change in Hungary. Acta Silvatica et Lignaria Hungarica 4: 17-27.

Spiecker H., Mielikeinen K., Köhl M. \& Skovsgaard J.P. (eds) 1996: Growth trends of European forests. European Forest Institute, Research report 5, Springer-Verlag Berlin Heidelberg.

Szabados I. 2007: Időjárási fluktuáció hatása a produkcióra dendrokronológiai kutatások alapján. In: Mátyás Cs. \& Vig P. (eds): Erdő és klíma V., Nyugat-Magyarországi Egyetem, Sopron, 295-306.

Ulrich B. 1989: Effect of acidic Precipitation on Forest Ecosystem in Europe. In: Adriano D.C. \& Johnson A. H. (eds): Acidic Precipitation Vol. 2., Springer-Verlag New York, 189-272.

Érkezett: 2018. május 2.

Közlésre elfogadva: 2018. május 30. 